\title{
Clinical Evaluation of Somatostatin as a Potential Adjunct to Insulin in the Management of Diabetes Mellitus
}

\author{
J.E. Gerich, T. A. Schultz, S. B. Lewis, and J.H. Karam \\ Clinical Investigation Center, Naval Regional Medical Center, Oakland, California, and the Metabolic Research Unit and Department \\ of Medicine, University of California Medical Center, San Francisco, California, USA
}

\begin{abstract}
Summary. To determine whether somatostatin, an inhibitor of glucagon and growth hormone secretion, might be useful as an adjunct to insulin in the management of diabetic hyperglycaemia, seven insulinrequiring diabetic men were given somatostatin (100 $\mu \mathrm{g} / \mathrm{h}$, IV) continuously for 3 days after their diabetes had been treated intensively by diet and insulin on a metabolic ward. During infusion of somatostatin and despite reduction in average insulin dose exceeding $50 \%$, there was improvement in diabetic control as assessed by postprandial hyperglycaemia, 24-h glycosuria and the average daily serum glucose level and its fluctuation; when somatostatin was discontinued, but insulin doses held constant, diabetic control rapidly worsened. No adverse effects were observed. These results indicate that somatostatin plus insulin can be a more effective regimen than insulin alone in controlling diabetic hyperglycaemia. A longer acting and more selective somatostatin preparation may prove useful as an adjunct to insulin in the management of diabetes.
\end{abstract}

Key words: Somatostatin, glucagon, insulin, growth hormone, treatment of diabetes.

Impaired insulin secretion or action is widely acknowledged to be the prime factor responsible for carbohydrate intolerance in both juvenile-onset and adult-onset varieties of diabetes mellitus [1,2]. Conventional insulin therapy, however, has not proved uniformly successful in normalizing blood glucose $[3,5]$ or in preventing long-term complications [6, 7]. Consequently, improved methods for insulin delivery, such as an artificial pancreas and transplantation of pancreatic tissue are currently being sought. Since factors other than insulin lack, such as glucagon $[8,9]$ and growth hormone excess $[9,11]$, may also contribute to the severity of diabetic hyperglycaemia, the removal or reduction of such insulin antagonists might improve metabolic control in diabetes.

This view is supported by recent studies employing somatostatin $[12,13]$ which, in addition to other actions $[12,14-16]$, inhibits the secretion of glucagon [17] and growth hormone [13]. In short-term experiments infusion of this peptide reduced both fasting [18-21] and postprandial hyperglycaemia [22-24] in insulin-requiring diabetic patients and rendered exogenous insulin more effective [22, 23]. This suggests that such an agent might act as an adjunct to insulin in the treatment of diabetes mellitus. Therefore, the present investigation was undertaken to determine whether combined use of somatostatin and insulin would be better than the optimal use of insulin alone.

\section{Materials and Methods}

\section{Subjects}

Informed consent was obtained from seven men with diabetes mellitus requiring insulin therapy. All were in good health and took no medications except insulin; their clinical characteristics are shown in Table 1. Three had ketosis-prone diabetes as evidenced by recent episodes of ketoacidosis; the remaining patients (two of whom were slightly obese) had ketosis-resistant adult-onset diabetes.

\section{Experimental Protocol}

Patients were admitted to a metabolic ward and placed on a diet designed to maintain their weight 
Table 1. Clinical characteristics of diabetic subjects

\begin{tabular}{|c|c|c|c|c|c|}
\hline $\begin{array}{l}\text { Sub- } \\
\text { ject }\end{array}$ & $\frac{\text { Age }}{\text { (Yr) }}$ & $\% \overline{I B W}^{\mathrm{a}}$ & Ketoacidosis & $\frac{\text { Duration }}{\text { Diabetes }}$ & Insulin therapy \\
\hline 1 & 21 & 93 & + & 6 wks & 6 wks \\
\hline 2 & 22 & 97 & + & $6 \mathrm{wks}$ & $6 \mathrm{wks}$ \\
\hline 3 & 25 & 98 & + & 7 yrs & 7 yrs \\
\hline 4 & 46 & 104 & - & 6 yrs & $3 \mathrm{yrs}$ \\
\hline 5 & 59 & 139 & - & 15 yrs & 2 wks \\
\hline 6 & 69 & 110 & - & 4 yrs & $1 \mathrm{wk}$ \\
\hline 7 & 53 & 125 & - & 13 wks & 13 wks \\
\hline
\end{tabular}

a Metropolitan Life Insurance Co. tables

and facilitate optimal diabetic control. The diet contained $2032 \mathrm{Kcal} /$ day as $50 \%$ carbohydrate (C), $30 \%$ fat $(\mathrm{F})$, and $20 \%$ protein $(\mathrm{P})$ distributed over 5 meals taken at $0800,1100,1300,1800$, and 2200 $\mathrm{h}$ as follows: breakfast $(26 \mathrm{~g} \mathrm{P}, 21 \mathrm{~g} \mathrm{~F}, 58 \mathrm{~g}$ $\mathrm{C}-518 \mathrm{Kcal})$, midmorning snack $(1 \mathrm{~g} \mathrm{P}, 2 \mathrm{~g} \mathrm{~F}$, $28 \mathrm{~g} \mathrm{C}-131 \mathrm{Kcal})$, lunch $(23 \mathrm{~g} \mathrm{P}, 19 \mathrm{~g} \mathrm{~F}, 64 \mathrm{~g}$ C - $518 \mathrm{Kcal})$, dinner $(38 \mathrm{~g} \mathrm{P}, 20 \mathrm{~g} \mathrm{~F}, 79 \mathrm{~g}$ $\mathrm{C}-652 \mathrm{Kcal})$, and evening snack $(13 \mathrm{~g} \mathrm{P}, 7 \mathrm{~g} \mathrm{~F}$, 26 g C -213 calories). These diets were maintained constant throughout the study. Additionally patients were placed on divided doses of insulin consisting of mixtures of Soluble and NPH insulin (Eli Lilly Monocomponent $\left.{ }^{\circledR}\right)$ given subcutaneously $1 / 2$ $\mathrm{h}$ before breakfast and dinner. Insulin regimes were individualized over a 5- to 7-day equilibration period so that serum glucose values obtained prior to each meal were maintained at a level considered the lowest possible without inducing symptomatic hypoglycaemia. The regime for each subject is shown in Table 2 . In several instances patients experienced transient mild symptoms of hypoglycaemia, but these passed without necessitating intervention.

Upon completion of the equilibration period the patients were studied for 7 consecutive days: blood was sampled at hourly intervals from 0700 to 2200 $\mathrm{h}$ and thence at 2400,0400, and $0700 \mathrm{~h}$ through an indwelling 18 -gauge angiocath $^{\circledR}$ inserted into a forearm vein and kept patent by a slow infusion of $0.9 \% \mathrm{NaCl}$ solution. To conserve blood, serum glucose levels alone were determined on days 1 and 7 ; whereas on days 2 through 6 serum glucose, free insulin, growth hormone, and plasma glucagon levels were also determined. During the first 2 days (control period 1) the previously "optimized" insulin regimen was maintained. On the morning of the third experimental day between 0700 and $0730 \mathrm{~h}$ an infusion of synthetic linear somatostatin $(100 \mu \mathrm{g} / \mathrm{h})$ (kindly supplied by Doctors Roger Guillemin and Jean River of the Salk Institute, San Diego, California, and under IND 10416 from the U. S. Food and
Drug Administration) was started in a forearm vein of the arm contralateral to the one used for blood sampling. The somatostatin was dissolved in $0.9 \%$ $\mathrm{NaCl}$, sterilized by passage through a millipore ${ }^{\circledR}$ filter $(0.22 \mu)$ and infused as previously described [25] except for the different infusion rate $(100 \mu \mathrm{g} / \mathrm{h}$ vs. $500 \mu \mathrm{g} / \mathrm{h})$. Each day of the 3-day somatostatin infusion, while patients were maintained on a constant diet, insulin doses were reduced stepwise to avoid anticipated hypoglycaemia [22] (see Table 2 for insulin given each day) so that by the third day of the somatostatin infusion patients were receiving less than $50 \%$ of the insulin they had received during the first control period. This dose of insulin was then maintained for an additional 2 days (control period 2) after stopping the somatostatin infusions between 0700 and $0730 \mathrm{~h}$ on the morning of the sixth experimental day.

\section{Analytical Determination}

Serum glucose was determined enzymatically (glucose oxidase) using a Yellow Springs ${ }^{\circledR}$ glucose analyzer. Plasma glucagon and serum growth hormone were measured by radioimmunoassay as previously described [26]. Because insulin antibodies in the sera of some patients would interfere with the insulin immunoassay, these antibodies and any insulin bound to antibody were removed from sera prior to the immunoassay of insulin using the polyethylene glycol extraction method of Nakagawa et al. [27] and then insulin levels were determined in triplicate as free insulin in a solid phase assay system. Recovery of insulin added to normal serum averaged $93 \pm 1 \%$ using this technique. Briefly, 0.5 $\mathrm{ml}$ serum was added to $0.5 \mathrm{ml}$ chilled $25 \%$ (w/w) polyethylene glycol (average molecular weight 6000-7500, Matheson, Coleman \& Bell). The mixture was immediately agitated with a vortex mixer for $1 \mathrm{~min}$ and then centrifuged $(1600 \mathrm{~g})$ for $45 \mathrm{~min}$ at $4^{\circ} \mathrm{C}$. Supernatant, $0.1 \mathrm{ml}$, and similarly extracted human insulin standards (Burroughs Wellcome), made up in $0.4 \mathrm{~mol} / 1$ glycine buffer $\mathrm{pH} 8$ containing $1 \mathrm{~g} / 100 \mathrm{ml}$ human serum albumin, were added to polystyrene tubes (\# 2052 Falcon) previously coated with insulin antibody (Miles Laboratories). In the coating procedure $1 \mathrm{ml}$ insulin antibody, diluted to $1: 1000$ in $0.4 \mathrm{~mol} / \mathrm{l}$ glycine buffer $\mathrm{pH}$ 8 containing no albumin, was pipetted in assay tubes, allowed to stand $2 \mathrm{~h}$ at room temperature and then aspirated. Coated tubes were washed twice with $1.3 \mathrm{ml}$ human serum albumin, $1 \mathrm{~g} / \mathbf{1 0 0} \mathrm{ml}$, in $9 \mathrm{~g} / \mathrm{l} \mathrm{NaCl}$, inverted and allowed to dry overnight at $4^{\circ} \mathrm{C}$. Tubes were used within 1 wk of coating and the coating solution was reused only once. To the 


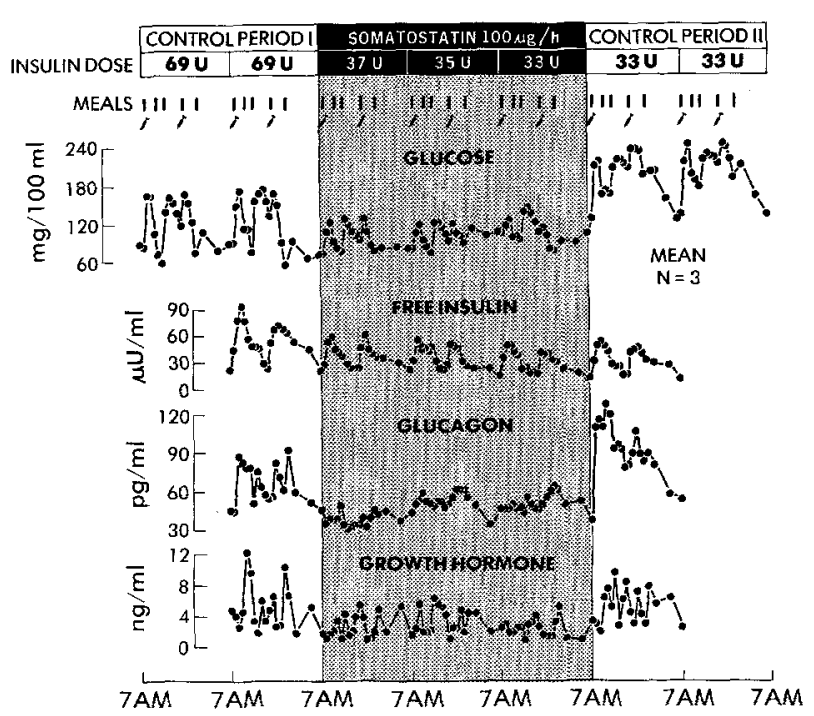

Fig. 1. Effect of 3-day somatostatin infusion on glucose, free insulin, glucagon and growth hormone levels in three juvenile-onset type diabetic subjects

above assay mixture, $0.5 \mathrm{ml}^{125} \mathrm{I}$ insulin $(70-140$ $\mu \mathrm{Ci} / \mu \mathrm{g}$, Union Carbide) was added. After gentle mixing tubes were incubated overnight at $4^{\circ} \mathrm{C}$ and subsequently aspirated, washed twice with distilled water, and counted. The sensitivity of this system is $5 \mu \mathrm{U} / \mathrm{ml}$ with an interassay variation less than $15 \%$.

Daily glucose, creatinine, and amylase content in 24 hour urine specimens and daily serum total bilirubin, cholesterol, triglyceride, uric acid, alkaline phosphatase, glutamic oxaloacetic transaminase, lactic dehydrogenase, and serum electrolyte (sodium, potassium, chloride, and bicarbonate) levels were determined by Technicon Auto Analyzer ${ }^{\circledR}$. Daily RBC, WBC, and platelet counts were determined using a Coulter Counter ${ }^{\circledR}$. Template bleeding times on the day prior to, the last day of, and the day after the somatostatin infusions, were determined as previously described [28].

\section{Calculations and Statistical Analyses}

An "average diurnal glucose level" for each patient was calculated by dividing the sum of all glucose determinations for a given $24-\mathrm{h}$ period by the number of determinations $(n=18)$. As an indicator of fluctuation in glucose levels throughout the day (and hence stability of diabetic control) standard deviations of the "average diurnal glucose level" were calculated from glucose determinations made throughout the experimental days in each patient using computer programme STI-01 (Texas Instruments). Statistical significance was evaluated using paired two-tailed Student $t$ tests after checking

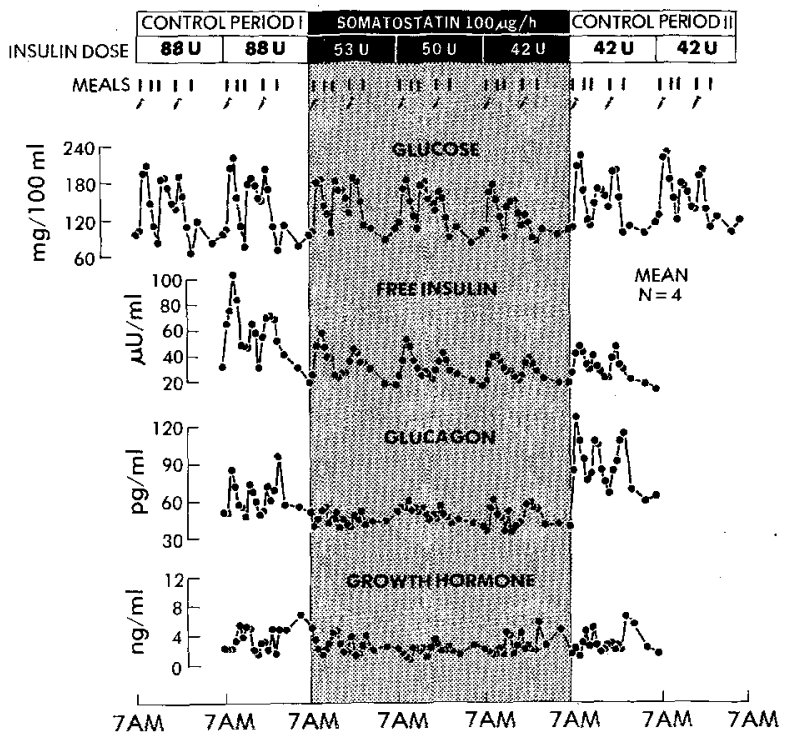

Fig. 2. Effect of 3-day somatostatin infusion on glucose, free insulin, glucagon and growth hormone levels in four adult-onset type insulin-requiring diabetic subjects

for parametric distribution, unless stated otherwise. All data are presented as mean \pm SEM.

\section{Results}

Mean serum glucose, free insulin, growth hormone and plasma glucagon levels during the 7 consecutive days of the study are shown separately for the three juvenile-onset type diabetic subjects and the four adult-onset type diabetic subjects in Figures 1 and 2 respectively. Insulin doses, average diurnal serum glucose levels and its variability (standard deviation) and 24-hour glucosuria for each subject during each day of the study are given in Table 2. The same amount of insulin was administered to a given patient on the first 2 days. This averaged $79 \pm 9$ U per day given as a mixture of soluble and NPH insulin $1 / 2$ h before breakfast and dinner for the seven subjects. Insulin doses were similar in six of the subjects (67-86 U/day), but one adult-onset type diabetic received $125 \mathrm{U} /$ day, which resulted in a greater average insulin dose for this group. Diabetic control, as assessed by serum glucose levels, average diurnal glucose level and its variability, and 24 hour glucosuria was similar on each of the initial two control days for each group of subjects, indicating that a stable baseline had been achieved for subsequent studies. Slightly better control was achieved in the juvenile-onset type diabetic subjects, although both groups had excessive postprandial hyperglycaemia, elevated average diurnal serum glucose levels, and abnormally wide fluctuations in serum glucose levels throughout the day. 


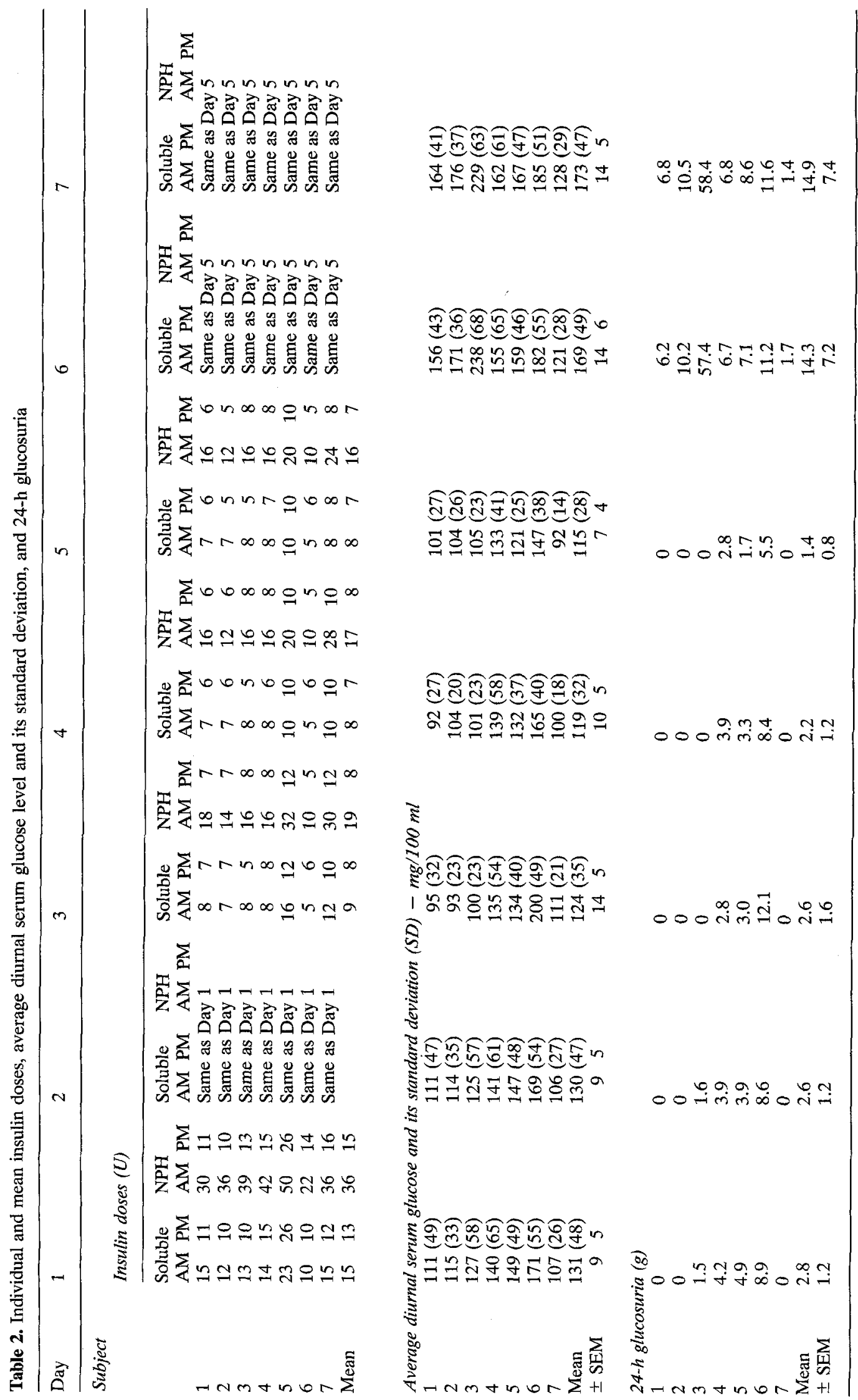




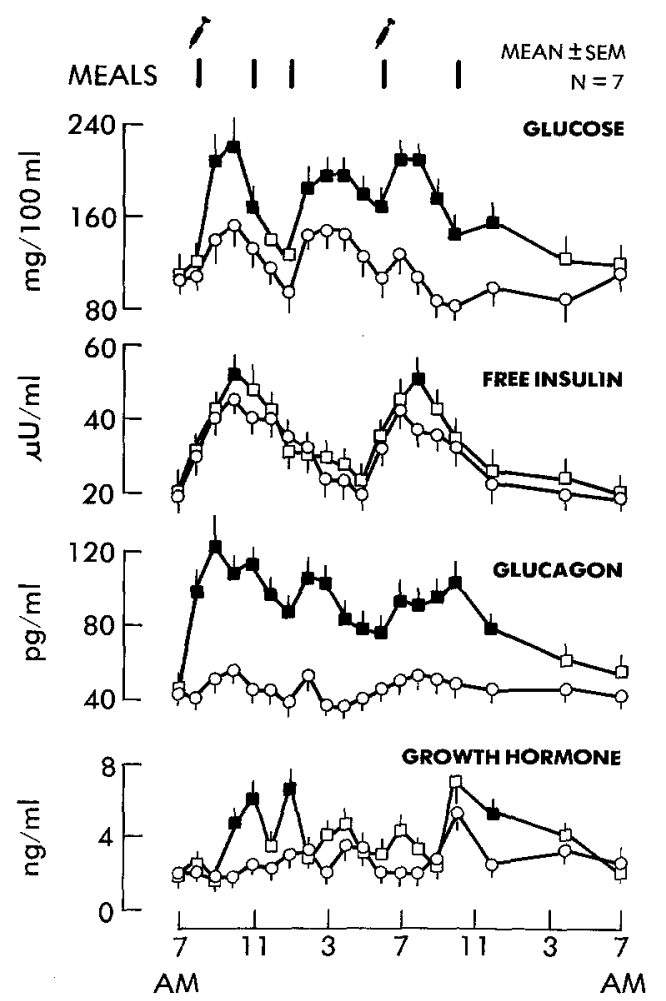

Fig. 3. Comparison of glucose, free insulin, glucagon and growth hormone levels during administration of identical quantities of insulin with (last day of somatostatin infusion) and without somatostatin (first day off somatostatin). Insulin alone 38U ( $\square$ ) when not significantly different, and ( $\square$ ) when significantly different $(\mathrm{p}<0.05)$ from insulin $38 \mathrm{U}$ plus somatostatin $(\mathrm{o}-\mathrm{o})$

During infusion of somatostatin continuously for the next 3 days, insulin doses were reduced a similar degree in each group of subjects, averaging for the seven patients $47 \pm 8,42 \pm 5$, and $38 \pm 3 \mathrm{U} /$ day on the first, second and third days of the somatostatin infusion respectively. In both groups diabetic control did not worsen despite this overall $50 \%$ reduction in insulin dosage. The juvenile-onset type diabetics had an immediate diminution in hyperglycaemia, which persisted throughout the infusion of somatostatin; diabetic control in the adult-onset group also improved, but this was not clearly evident until the third day of the somatostatin infusion. In both types of diabetic subjects diabetic control deteriorated immediately after stopping the somatostatin infusion, although insulin doses were unchanged; in all subjects average diurnal serum glucose levels and its variability and 24 hour glucosuria increased (Table 2). Although the adult-onset diabetic subjects' control deteriorated less than that in the juvenile-onset group, similar degrees of deterioration were observed on the first and second days after discontinuation of the somatostatin in each group, indicating the reproducibility and persistence of the effect.

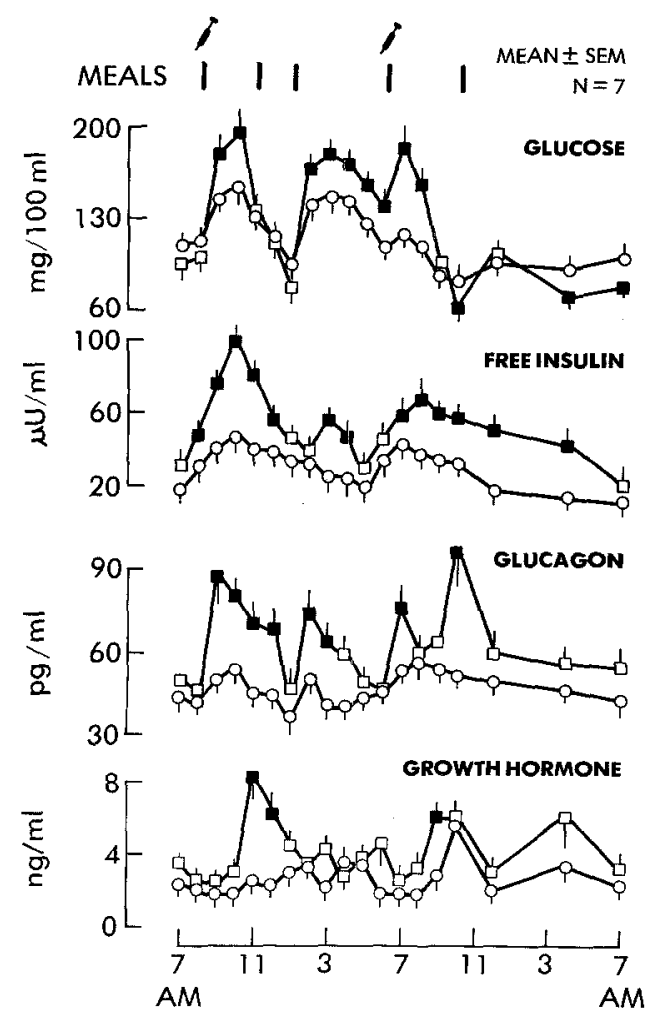

Fig. 4. Comparison of glucose, free insulin, glucagon and growth hormone levels during administration of somatostatin plus insulin (last day of somatostatin infusion) vs. twice as much insulin alone (day immediately preceding start of somatostatin infusion). Insulin alone $79 U(\square \square)$ and ( $\square$ ( ) when significantly different $(\mathrm{p}<0.05)$ from insulin $38 \mathrm{U}$ plus somatostatin $(\mathrm{o}-\mathrm{o})$

Comparison of Glucose, Free Insulin, Glucagon and Growth Hormone Levels During Administration of Identical Quantities of Insulin with and without Somatostatin (Fig. 3)

Since both juvenile and adult-onset type of diabetic subjects responded similarly during the study, their data were pooled for statistical evaluation. Figure 3 compares the mean ( \pm SEM) serum glucose, free insulin, growth hormone and plasma glucagon levels for the seven subjects observed on days 5 and 6 of the study during administration of identical quantities of insulin, with and without somatostatin, respectively. At almost all sampling times serum glucose and glucagon levels were significantly lower during infusion of somatostatin. The average diurnal glucose level with somatostatin $(114 \pm 9 \mathrm{mg} / 100$ $\mathrm{ml}$ ) was significantly lower than that found without it $(168 \pm 14 \mathrm{mg} / 100 \mathrm{ml}, \mathrm{p}<0.01)$. Moreover, there was less variability in glucose levels throughout the day during infusion of somatostatin, as indicated by the standard deviations of glucose determinations obtained throughout the day in each patient (Table $2, \mathrm{p}<0.01$ ). 
Circulating free insulin levels were virtually identical on both days, although occasionally higher values were found without somatostatin. Transient rises in both glucagon and growth hormone levels were observed during infusion of somatostatin, reflecting incomplete suppression of the release of these hormones using an infusion of $100 \mu \mathrm{g} /$ /itre somatostatin. Indeed growth hormone levels were significantly lower than control values at only a few sampling times during infusion of somatostatin.

Comparison of Glucose, Free Insulin, Glucagon, and Growth Hormone Levels during Administration of Somatostatin Plus Insulin with Those Observed during Administration of Twice as Much Insulin Alone (Fig. 4)

Figure 4 compares glucose, free insulin, glucagon and growth hormone levels in the seven diabetic subjects on days 2 and 5 of the study when, respectively, subjects received an average of $79 \mathrm{U}$ insulin/ day alone and $38 \mathrm{U}$ insulin/day with somatostatin. As anticipated, serum free insulin levels, especially postprandial values, were much higher when patients received the higher dose of insulin without somatostatin. Despite this, serum glucose rose to significantly higher levels after breakfast, lunch and dinner than when patients received half as much insulin plus somatostatin. This resulted in significantly higher average diurnal glucose levels $(131 \pm 9$ vs. $114 \pm 9, p<0.01$ ), although serum glucose levels prior to the evening snack and during the early morning hours were significantly lower when patients received the higher dose of insulin without somatostatin. Accordingly, fluctuation in glucose levels throughout the day (standard deviation of average diurnal glucose levels $(46 \pm 5$ vs. 28 $\pm 4 \mathrm{mg} / 100 \mathrm{ml}, \mathrm{p}<0.01$ ) was less during administration of somatostatin and less insulin. Plasma glucagon levels were significantly lower during infusion of somatostatin at most sampling times, while growth hormone levels were only occasionally lower than those found during administration of the higher dose of insulin without somatostatin.

\section{Adverse Effects}

No symptoms or signs of untoward effects were observed during the course of these studies. The patients' appetites and weight remained stable; no nausea, vomiting, abdominal pain, or diarrhoea occurred. No change in urinary amylase and creatinine excretion, serum electrolytes, creatinine, uric acid, cholesterol, triglyceride, glutamic oxaloacetic transaminase, lactic dehydrogenase, or total bilirubin levels was observed. Red blood cell count decreased significantly, but this was within the range anticipated from the volume of blood sampled during the course of the study $(\simeq 200 \mathrm{cc} /$ day). No change in white blood cell count, platelet count, or template bleeding time was observed (Full data available from the authors).

\section{Discussion}

In short-term studies somatostatin reduces both fasting [18-21] and postprandial hyperglycaemia [22-24] in insulin-dependent diabetic patients. The present investigation was undertaken to determine whether during a more prolonged period of observation addition of somatostatin would offer any advantage over the optimal use of diet and insulin alone. It is to be emphasized, therefore, that prior to administering somatostatin diabetic hyperglycaemia was managed intensively on a metabolic ward with diet manipulation and use of twice-a-day mixtures of soluble and NPH insulin titrated in each patient so as to diminish serum glucose levels just short of hypoglycaemia. The degree of control achieved on this intensive regimen (as assessed by serum glucose levels, average diurnal glucose level, fluctuation of glucose levels and 24 hour glycosuria) would be considered 'good' to 'excellent' by most standards [5, 29-31], but was clearly not normal. In most instances greater amounts of insulin than those chosen as optimal had been used during the preliminary equilibration period; this did result in lower postprandial serum glucose levels, but not without inducing subsequent hypoglycaemia. Thus, in the patients studied who were not considered "brittle" or insulin resistant, the degree of control achieved was probably the best obtainable under the circumstances.

During the infusion of somatostatin over the next three days, while insulin doses were reduced stepwise in excess of $50 \%$, diabetic control improved as indicated by significantly lower postprandial serum glucose values, lower average diurnal glucose levels, and less fluctuation in serum glucose throughout the day. These results appeared to be directly related to the infusion of somatostatin, since diabetic regulation rapidly deteriorated and was worse on both days during the second control period after discontinuation of the somatostatin infusion while the insulin doses were held constant. Thus somatostatin plus insulin can be a more effective therapeutic regimen than insulin alone, even when twice as much insulin is administered alone under presumably optimal conditions. 
The maximum therapeutic benefit from somatostatin was probably not achieved in these studies. First of all, no attempt was made to determine the optimal combination of insulin and somatostatin. Rather a suboptimal dose of insulin plus somatostatin was compared to an optimal insulin regimen. Secondly, the dose of somatostatin used in accordance with current Food and Drug Administration limitations was clearly not maximally effective since glucagon and growth hormone levels were not suppressed to the degree found with higher doses of somatostatin $[22,28]$. Thirdly, the diabetic patients studied were stable and relatively easy to control; presumably greater advantage may accrue to "brittle" diabetic patients.

The effects on blood glucose levels observed during administration of somatostatin have been attributed generally to its suppression of glucagon and growth hormone secretion [9, 19, 21, 22, 25, 32-34] since it has no intrinsic effects on glucose production $[34,35]$ or utilization [35]. The results of the present study would support this, since circulating glucagon and growth hormone levels were diminished during infusion of somatostatin and the former generally paralleled changes in diabetic control. However, because of the effects of this peptide on the secretion of other hormones $[12,14,16]$ and its effects on gastrointestinal function [15], particularly diminution of splanchnic blood flow [24], delayed gastric emptying [15], inhibition of pancreatic exocrine $[36,37]$ and gastric acid secretion $[38,39]$ and delayed xylose absorption [24], mechanisms other than or in addition to suppression of glucagon or growth hormone secretion could have been involved. No gastrointestinal symptoms were observed during the course of the study, and patient weights remained constant suggesting that malabsorption or severe perturbation of gastrointestinal function probably did not occur. Indeed, of the many variables monitored for possible adverse effects, including platelet count and template bleeding time [41], only red blood cell count was altered; and this could readily be explained from the amount of blood sampled.

Because of its short half-life $(\approx 2$ minutes) [40] and potentially undesirable effects (e. g. inhibition of thyrotropin secretion) $[13,15-17]$, it seems unlikely that somatostatin itself, as presently available, can be administered therapeutically on a long-term basis. However, the present demonstration that such an agent plus insulin can be superior to insulin alone in the treatment of diabetes mellitus will stimulate the development of a longer acting and more specific preparation.
Acknowledgements. This study was supported in part by funds provided by the Bureau of Medicine and Surgery, Navy Department, for CIP 6-48-859 and in part by grants from the Susan Greenwall Foundation of New York City, the Levi J. and Mary Skaggs Foundation, Oakland, California, the Ellis L. Phillips Foundation of Jericho, New York, and by USPHS grant AM $1276(05)$.

The opinions or assertions contained herein are the private ones of the authors and are not to be construed as official or as reflecting the views of the Navy Department or the naval service at large.

We wish to thank our patients for their cheerful cooperation in these studies; the metabolic ward corpsmen, dieticians, and nursing staff for their dedicated collaboration; HM3 L. Adam, Mr. G. Schmidt, and Ms. G. Gustafson for excellent technical help; and Mrs. Margaret Nielson for editorial assistance.

\section{References}

1. Kipnis, D. M.: Insulin secretion in diabetes mellitus. Ann. Intern. Med. 69, 891-901 (1969)

2. Levine, R., Haft, D. E.: Carbohydrate homeostasis. N. Engl. J. Med. 283, 175-183, 237-246 (1970)

3. Kopf, A., Tchobroutsky, G., Eschwege, E.: Serial postprandial blood glucose levels in 309 subjects with and without diabetes. Diabetes 22, 834-840 (1973)

4. Service, F.J., Molnar, G. D., Rosevear, J. W., Ackerman, E., Gatewood, L. C., Taylor, W.F.: Mean amplitude of glycemic excursions, a measure of diabetic instability. Diabetes 19, 644-655 (1970)

5. Malone, J.I., Hellrung, J.M., Malphus, E. W., Rosenbloom, A.L., Grgic, A., Weber, F.T.: Good diabetic control - a study in mass delusion. J. Pediatr. 88, 943-947 (1976)

6. Knowles, H. C. Jr.: Control of diabetes and the progression of vascular disease. In: M. Ellenberg, H. Rifkin (Eds.): Diabetes mellitus theory and practice, pp. 666-673. New York: McGraw-Hill Book Company 1970

7. Goldner, M.G., Knatterud, G.L., Prout, T.E.: Effects of hypoglycemic agents on vascular complications in patients with adult-onset diabetes. III. Clinical implications of the UGDP results. JAMA 218, 1400-1410 (1971)

8. Unger, R.H.: Diabetes and the alpha cell. Diabetes 25, 136-151 (1976)

9. Gerich, J.E., Lorenzi, M., Bier, D.M., Tsalikian, E., Schneider, V., Karam, J.H., Forsham, P.H.: Effects of physiologic levels of glucagon and growth hormone on human carbohydrate and lipid metabolism: studies involving administration of exogenous hormone during suppression of endogenous hormone secretion with somatostatin. J. Clin. Invest. 57, 875-884 (1976)

10. Luft, R., Guillemin, R.: Growth hormone and diabetes in man. Old concepts - new implications. Diabetes 23, 783-787 (1974)

11. Pearson, O.H., Dominquez, J.M., Greenberg, E., Pazianos, A., Ray, B.S.: Diabetogenic and hypoglycemic effects of human growth hormone. Trans. Assoc. Am. Physicians 73, 217-266 (1960)

12. Vale, W., Brazeau, P., Rivier, C., Brown, M., Boss, B., Rivier, J., Burgus, R., Ling, N., Guillemin, R.: Somatostatin. Recent Prog. Horm. Res. 31, 365-397 (1975)

13. Burgus, R., Brazeau, P., Vale, W.: Isolation and determination of the primary structure of somatostatin (a somatotropin release inhibiting factor) of ovine hypothalamic origin. DHEW Publications 74-612 (NIH) 144-158 (1973) 
14. Guillemin, R., Gerich, J.E.: Somatostatin: physiological and clinical significance. Annu. Rev. Med. 27, 379-388 (1976)

15. Konturek, S.J.: Somatostatin and the gastrointestinal secretions. Scand. J. Gastroenterol. 11, 1-4 (1976)

16. Lucke, C., Mitzkat, H.J., von zur Mühlen, A.: Somatostatin - a review. Klin. Wochenschr. 54, 293-301 (1976)

17. Koerker, D. J., Ruch, W., Chideckel, E., Palmer, J., Goodner, C. J., Ensinck, J., Gale, C. C.: Somatostatin: hypothalamic inhibitor of the endocrine pancreas. Science 184, 482-484 (1974)

18. Del Guercio, M. J., di Natale, B., Gargantini, L., Garlaschi, C., Chiumello, G.: Effect of somatostatin on blood sugar, plasma growth hormone, and glucagon levels in diabetic children. Diabetes 25, 550-553 (1976)

19. Gerich, J.E., Lorenzi, M., Schneider, V., Karam, J.H., Rivier, J., Guillemin, R., Forsham, P.H.: Effects of somatostatin on plasma glucose and glucagon levels in human diabetes mellitus. N. Engl. J. Med. 291, 544-547 (1974)

20. Lundbaek, K., Hansen, Aa. P., Ørskov, H., Christensen, S. E., Iversen, J., Seyer-Hansen, K., Alberti, K. G. M.M., Whitefoot, R.: Failure of somatostatin to correct manifest diabetic ketoacidosis. Lancet 1976 I, 215-218

21. Gerich, J.E., Schneider, V., Lorenzi, M., Tsalikian, E., Karam, J. H., Bier, D. M., Forsham, P. H.: Role of glucagon in human diabetic ketoacidosis: studies using somatostatin. Clin. Endocrinol. 5 (Suppl), 299s-305s (1976)

22. Gerich, J.E., Lorenzi, M., Karam, J.H., Schneider, V., Forsham, P. H.: Abnormal pancreatic glucagon secretion and postprandial hyperglycemia in diabetes mellitus. JAMA 234, 159-165 (1975)

23. Meissner, C., Thum, Ch., Beischer, W., Winkler, G., Schröder, K.E., Pfeiffer, E.F.: Antidiabetic action of somatostatin - assessed by the artificial pancreas. Diabetes 24, 988-996 (1975)

24. Wahren, J., Felig, P.: Somatostatin (SRIF) and glucagon in diabetes: failure of glucagon suppression to improve I. V. glucose tolerance and evidence of an effect of SRIF on glucose absorption. Clin. Res. 24, 461A (1976)

25. Gerich, J. E., Lorenzi, M., Bier, D. M., Schneider, V., Tsalikian, E., Karam, J.H., Forsham, P. H.: Prevention of human diabetic ketoacidosis by somatostatin. N. Engl. J. Med. 292, 985-989 (1975)

26. Gerich, J. E., Schneider, V., Dippe, S. E., Langlois, M., Noacco, C., Karam, J.H., Forsham, P. H.: Characterization of the glucagon response to hypoglycemia in man. J. Clin. Endocrinol. Metab. 38, 77-82 (1974)

27. Nakagawa, S., Nakayama, H., Sasaki, T., Yoshino, K., Yu, Y.Y., Shinozaki, K., Aoki, S., Mashimo, K.: A simple method for the determination of serum free insulin levels in insulin-treated patients. Diabetes 22, 590-600 (1973)

28. Mielke, C. H., Gerich, J. E., Lorenzi, M., Tsalikian, E., Rodvien, R., Forsham, P.H.: The effect of somatostatin on coagulation and platelet function in man. N. Engl. J. Med. 293, 480-483 (1975)
29. Traisman, H. S.: Management of juvenile diabetes mellitus, p. 54. St. Louis: C. V. Mosby Company 1971

30. Marble, A.: Therapy: criteria of control in diabetes mellitus diagnosis and treatment, vol. 1, T. Danowski, (Ed.), pp. 69-71. New York: American Diabetes Association 1964

31. Lukens, F.D., Franklin, S. N.: Long-term diabetes without vascular disease. Med. Clin. North Am. 50, 1385-1391 (1966)

32. Chideckel, E.W., Palmer, J., Koerker, D.J., Ensinck, J., Davidson, M. B., Goodner, C. J.: Somatostatin blockade of acute and chronic stimuli of the endocrine pancreas and the consequences of this blockade on glucose homeostasis. J. Clin. Invest. 55, 754-762 (1975)

33. Alford, F.P., Bloom, S.R., Nabarro, J.D.N., Hall, R., Besser, G. M., Coy, D. H., Kastin, A.J., Schally, A. V.: Glucagon control of fasting glucose in man. Lancet $1974 \mathrm{II}, 974-976$

34. Sakurai, H., Dobbs, R., Unger, R. H.: Somatostatin-induced changes in insulin and glucagon secretion in normal and diabetic dogs. J. Clin. Invest. 54, 1395-1402 (1974)

35. Gerich, J.E., Bier, D., Haas, R., Wood, C., Byrne, R., Penhos, J.: In vitro and in vivo effects of somatostatin on glucose, alanine, and ketone body metabolism in the rat, p. 128. Prog. 57th Annual Meeting of the Endocrine Society, New York, June 18-20, 1975

36. Boden, G., Sivitz, M.C., Owen, O.E., Essa-Koumar, N., Landar, J.H.: Somatostatin suppresses secretin and pancreatic exocrine secretion. Science 190, 163-165 (1975)

37. Konturek, S. J., Tasler, J., Obtulowicz, W., Coy, D. H., Schally, A.V.: Effect of growth hormone-release inhibiting hormone on hormones stimulating exocrine pancreatic secretion. J. Clin. Invest. 58, 1-6 (1976)

38. Bloom, S. R., Mortimer, C. H., Thorner, M.O., Besser, G.M., Hall, R., Gomez-Pan, A., Roy, V.M., Russell, R. C. G., Coy, D.H., Kastin, A. J., Schally, A. V.: Inhibition of gastrin and gastric acid secretion by growth-hormone release-inhibiting hormone. Lancet 1974 II, 1106-1109

39. Raptis, S., Dollinger, H.C., von Berger, L., Schlegel, W. Schröder, K., Pfeiffer, E.: Effects of somatostatin on gastric secretion and gastrin release in man. Digestion 13, 15-26 (1975)

40. Ensinck, J. W., Laschansky, E., Knoeber, M., Johnson, D., Benson, J., Goodner, C. J.: Distribution of somatostatin (S) measured by radioimmunoassay. Clin. Res. 24, 155A (1976)

41. Koerker, D. J., Harker, L.A., Goodner, C. J.: Effects of somatostatin on hemostasis in baboons. N. Engl. J. Med. 293, 476-479 (1975)

Received: December 10, 1976, and in revised form: May 18, 1977

Dr. John E. Gerich

Diabetes and Metabolism Research Laboratory

Mayo Clinic

Rochester, MN 55901

USA 